\title{
Knowledge, attitudes, and perceptions on genetically modified mosquitoes: Case for sterile mosquito release in Grenada
}

\author{
Anjali Ghodasara, Marisa Deliso, Satesh Bidaisee* \\ St. George's University, School of Medicine, Grenada, West Indies, Grenada
}

Received: September 28, 2016

Accepted: January 2, 2017

Online Published: February 8, 2017

DOI: $10.5430 /$ jer.v3n1p57

URL: http://dx.doi.org/10.5430/jer.v3n1p57

\begin{abstract}
This study assessed knowledge, attitudes and perceptions of various stakeholders in Grenada regarding genetically modified organisms and the release of genetically modified mosquitoes. The study adopted a cross sectional design with a study population that comprised of members from seven stakeholder groups of civil society in Grenada. The sample population was obtained through a snowballing strategy and data collection for the study consisted of a semi-structured interview. Data was managed through the collection and reviewing of data from transcribed interview notes, as well as observations and interpretations made during the field collection. Interview recordings were analyzed to identify emerging themes. These themes were ranked according to the frequency with which they appeared, and main concepts identified by linking related themes. Most groups supported the use of genetically modified mosquitoes against Zika, but there were several varying concerns, including environmental worries and the impact of these organisms on humans. Many questioned the characteristics of Zika itself, and some believed Zika is a man-made virus created in a lab. Others doubted the link of Zika virus to microcephaly and other birth defects, and some were unsure if Zika virus is transmitted by mosquitoes. There is a wide range of differing knowledge, attitudes, and perceptions towards genetically modifying technology in general and towards mosquitoes in response to Zika.
\end{abstract}

Key Words: Zika, Genetically modified mosquito, Mosquito, Zoonotic disease

\section{INTRODUCTION}

Increasing prevalence of many vector-borne diseases has created new concerns and challenges for public health. ${ }^{[1]}$ Since many of these vectors are hematophagous insects, infections can spread rapidly from host to host during blood meals. ${ }^{[2]}$ Diseases transmitted by the Aedes aegypti mosquito include dengue, yellow fever, chikungunya and Zika (ZIKV), which is causing worldwide health concerns. During 2015 to 2016, 48 countries documented autochthonous transmission of ZIKV, including eleven countries that have reported locally acquired infections through sexual transmission, and five countries that have reported terminated outbreaks. ${ }^{[3]}$ The Brazilian Ministry of Health estimates that there were up to 1.3 million cases of ZIKV in 2015 and in the United States, 1,403 cases were reported as of July 20, 2016. ${ }^{[4,5]}$ These numbers are expected to rise as it is estimated that 2.17 billion people live in areas susceptible to ZIKV ${ }^{[6]}$ Human alterations of the natural environment together with changes to global temperature and weather patterns have challenged traditional measure for mosquito control requiring new approaches to be considered. ${ }^{[7]}$ The proposed method of Aedes aegypti mosquito vector control is the release of genetically

*Correspondence: Satesh Bidaisee; Email: sbidaisee@ @su.edu; Address: University Center, St. George, Grenada, West Indies, Grenada. 
modified mosquitos created by Oxitec in Grenada. Oxitec, a British biotechnology company, has recently genetically modified Aedes aegypti mosquitos using the Sterile Insect Technique (SIT). ${ }^{[8]}$ Pilot studies conducted by Oxitec report over a $90 \%$ reduction in the mosquito population which is a much greater level of control than has been achieved with use of insecticides. ${ }^{[1]}$ However, any considered approach to implement the genetically modified mosquito (GMM) technology in Grenada would require for an engaged discussion among all stakeholders. The purpose of this study is to determine and assess knowledge, attitudes and perceptions regarding the release of genetically modified mosquitos from various stakeholders in Grenada.

\section{MethodS}

The study was qualitative in nature and adopted a cross sectional design to determine the knowledge, attitudes, and perceptions (KAP) of Grenadians toward GMM release, with the goal of mosquito-borne infectious disease reduction. The study population was comprised of members from seven stakeholder groups of civil society in Grenada, including religious, hotel and tourism, government officials, vector control officers, and participants from local markets, main transportation terminal and bars and pubs from the general population. Community members who served as representatives from civil society included the seven noted stakeholder groups, with each group having a range of two to nine individual participants in a given stakeholder group. The sample population was obtained through a snowballing strategy in which stakeholder groups referred other groups to be approached, and within each group, participants identified as representatives from each stakeholder group recommended others for participation. Data collection for the study was conducted during the period May to June, 2016 and consisted of the study's investigators using a semi-structured interview template together with open ended questions to query participants on their KAP towards GMMs. Data was managed through the collection and reviewing of data from transcribed interview notes, as well as observations and interpretations made during the field collection. Possible biases from selection of participants as well as responses provided were managed through the process of allowing for saturation of data collected during the data collection. Interview recordings were analyzed to identify emerging themes. These themes were ranked according to the frequency with which they appeared, and main concepts identified by linking related themes.

\section{Results}

Table 1 shows responses regarding GMM perception and concerns from interviews with different stakeholders: religious, tourism, vector control, government, and the general public in market places, rum shops, and bus terminals, each group having a range of 2 to 9 individual participants.

Regarding GMM technology, 5/7, supported the use of GMM against ZIKV and other mosquito borne diseases; however, there were concerns expressed. 4/7 of the stakeholder groups also raised concerns about how the introduction of more mosquitos could become more of a nuisance rather than a benefit to the environment. All 4 groups specifically mentioned how the mongoose, which was introduced to Grenada to control the snake population, has now become a major pest itself. The largest concern from 5/7 stakeholders, including religious organizations, tourism, vector control and the general public, was the impact of GMM on humans. These concerns included the transfer of the gene or protein from the mosquito to human from either a bite or accidental ingestion and the effect of the gene on the human body. Two other issues that were identified during interviews were the creation of a new resistant species of mosquito and the effectiveness of the GMM by 3/7 and 4/7 stakeholders, respectively. Lastly, questions about effectiveness of GMM ability to reduce the population of the Aedes agypti mosquito were raised.

\section{DiscuSSION}

Support for GMM use to control mosquitoes was obtained but some varied issues identified depending on the stakeholder group that was consulted. Interestingly, the main reservation noted was among vector control officers who represent the implementation team if the proposed GMM technology was to be used. Addressing concerns by the vector control officers as well as developing their knowledge and understanding of GMM technology is critical.

The reduction in the reproductive potential of the Aedes aegypti mosquitos, thus restricting their population and the incidence of $\mathrm{ZIKV}$, dengue, chikungunya, and yellow fever is the projected benefits towards the use of GMM technology. ${ }^{\text {[9] }}$ Since 2009, Oxitec genetically modified Aedes aegypti mosquitos have been released in four other countries: Cayman Island, Malaysia, Brazil, and Panama. More than 90 million Oxitec mosquitos have been released in these countries and no adverse effects have been reported. ${ }^{[8]}$ Concerns regarding the transfer of the gene due to ingestion of the mosquitos were raised but no significant negative effects were reported from other studies that implemented the GMM or from its larvae. ${ }^{[10,11]}$ 
Table 1. Frequency of themes from interview responses regarding GMM position and concerns across different stakeholders in Grenada

\begin{tabular}{|c|c|c|c|c|c|c|c|c|}
\hline \multirow[t]{2}{*}{ Theme } & \multicolumn{8}{|c|}{ Stakeholder } \\
\hline & Religious & Tourism & Vector Control & Government & Market Place & Rum Shop & $\begin{array}{l}\text { Bus } \\
\text { Terminal }\end{array}$ & Frequency \\
\hline $\begin{array}{l}\text { In support of GM } \\
\text { mosquito }\end{array}$ & Positive position & $\begin{array}{l}\text { Yes if it } \\
\text { works }\end{array}$ & Some support & & $\begin{array}{l}\text { Would support } \\
\text { but lack } \\
\text { knowledge }\end{array}$ & $\begin{array}{l}\text { Would } \\
\text { support if it } \\
\text { works }\end{array}$ & & $5 / 7$ \\
\hline $\begin{array}{l}\text { Hesitant/ Cannot } \\
\text { Support GM } \\
\text { mosquito }\end{array}$ & $\begin{array}{l}\text { Genetic modification questioned by } \\
\text { Biblical principles: Creation principle } \\
\text { (God created all things perfect): } \\
\text { Genesis Chapter 1, Verse 31; } \\
\text { Ecclestiacs: Chapter 7, Verse } 29\end{array}$ & & $\begin{array}{l}\text { Some hesitation/does } \\
\text { not support }\end{array}$ & & & & $\begin{array}{l}\text { Unsure } \\
\text { because of } \\
\text { lack of } \\
\text { knowledge }\end{array}$ & $3 / 7$ \\
\hline $\begin{array}{l}\text { Nuisance-Eg. } \\
\text { Mongoose }\end{array}$ & & & $\begin{array}{l}\text { Mongoose: Introduce } \\
\text { animal to fight problem, } \\
\text { left with another } \\
\text { problem }\end{array}$ & $\begin{array}{l}\text { Mongoose: Unsure } \\
\text { introducing more } \\
\text { mosquito since it can } \\
\text { become nuisance }\end{array}$ & & $\begin{array}{l}\text { Mongoose } \\
\text { now a pest }\end{array}$ & $\begin{array}{l}\text { Mongoose } \\
\text { now a pest }\end{array}$ & $4 / 7$ \\
\hline $\begin{array}{l}\text { Environmental } \\
\text { Concerns }\end{array}$ & $\begin{array}{l}\text { Residual effects to environment, loss of } \\
\text { mosquitos }\end{array}$ & & $\begin{array}{l}\text { Lasting effect of } \\
\text { larvae/protein, impact on } \\
\text { fish }\end{array}$ & $\begin{array}{l}\text { Impact on ecosystem/ } \\
\text { environmental effects }\end{array}$ & & & & $3 / 7$ \\
\hline $\begin{array}{l}\text { Transfer/Mutae } \\
\text { Protein to } \\
\text { Humans/Health } \\
\text { Impacts }\end{array}$ & Impact of protein on human health & $\begin{array}{l}\text { Transferring } \\
\text { gene to } \\
\text { humans }\end{array}$ & $\begin{array}{l}\text { Transferring } \\
\text { gene/protein to humans }\end{array}$ & & $\begin{array}{l}\text { Impact of } \\
\text { protein on } \\
\text { human health }\end{array}$ & $\begin{array}{l}\text { Transfer of } \\
\text { protein to } \\
\text { humans }\end{array}$ & & $5 / 7$ \\
\hline $\begin{array}{l}\text { New Resistant } \\
\text { Mosquito } \\
\text { Species }\end{array}$ & Create new or resistant species & $\begin{array}{l}\text { "Super" } \\
\text { mosquito }\end{array}$ & $\begin{array}{l}\text { New Mutated/ } \\
\text { Aggressive/ Resistant } \\
\text { Mosquito }\end{array}$ & & & & & $3 / 7$ \\
\hline $\begin{array}{l}\text { Effectiveness of } \\
\text { GM mosquitos }\end{array}$ & & & $\begin{array}{l}\text { Males able to adapt- } \\
\text { proliferation, new } \\
\text { diseases }\end{array}$ & $\begin{array}{l}\text { DDT used but mosquito } \\
\text { came back }\end{array}$ & & $\begin{array}{l}\text { Concern if } \\
\text { actually } \\
\text { dies or } \\
\text { mutates }\end{array}$ & $\begin{array}{l}\text { Eggs may } \\
\text { still hatch } \\
\text { and transmit } \\
\text { disease }\end{array}$ & $4 / 7$ \\
\hline
\end{tabular}

The study participant groups including vector control, government officials, and religious organizations expressed hesitations regarding the residual effects these mosquitos could have on the environment. Questions about the impact on the ecosystem due to the reduction of the mosquito population as well as the effect on other species such as fish that consume mosquito larvae were also discussed. Historical experience with mongoose release to control pests was viewed as unsuccessful with the mongoose assuming the role of a pest and disease reservoir. The example of the mongoose therefore further presents a concern as it relates to release techniques towards controlling pests and diseases. Other issues identified by the study participants which are valid considerations relate to any residual effect of the altered gene which is introduced as well as the transfer of the altered gene into other species of animal or plant life.

Environmental concerns are valid issues that should be addressed in GMM campaigns using statistics and references from other countries, such as the Cayman Islands and Brazil, which have had great success with GMM with no reported adverse effects on the environment. Governmental officials further argued how DDT was used to reduce the mosquito population and although it initially worked, Aedes agypti

Published by Sciedu Press returned and thrived again. Participants also expressed concerns about the possibility of the eggs still hatching and continuing to transmit ZIKV and other viruses. Based on laboratory and release studies in Brazil, Malaysia, and Cayman Islands, up to $5 \%$ of Oxitec larvae can survive in optimal conditions with constant temperatures, adequate food supply, and no predators; however, these conditions will be very unlikely in the open environment. ${ }^{[8]}$

A public health program including an education component to sensitize the Grenadian population on the details and specifics of the proposed GMM technology approach will prove instructive towards gaining more informed attitudes and perceptions from the general public. The stakeholder consultation which involved a cross section of different interests in the Grenadian society should then be expanded towards a national conversation which will further inform the collective positions to inform the decision making by the government towards the use of the proposed GMM technology.

The findings of this study are within the limitations of error. The survey used was a semi-structured format which allowed for additional and different questions to emerge across dif- 
ferent participants and stakeholder groups which would have reduced the comparability of responses. The sample size used for the study is also small in terms of the number of participants engaged in each stakeholder group. The snowballing technique for sampling is also not consistent as a probability based approach which would have strengthened the statistical analysis. The study was also conducted during the initial outbreak of Zika in Grenada with the associated morbidity and mortality concerns which may have influenced participants' attitudes and perspectives on GMM technology.

\section{Conclusion}

The proposal to utilize GMM technology presents a new and different approach towards mosquito control. This study provides a general guide to inform a public consultation towards seeking consensus by understanding gaps in knowledge of the GMM and addressing attitudes and perceptions of GMM technology as an option for mosquito control.

\section{CONFlicts OF InTEREST Disclosure}

Authors declare that they have no competing interests.

\section{REFERENCES}

[1] Semenza JC, Menne B. Climate change and infectious diseases in Europe. Lancet Infectious Diseases. 2009; 9: 365-75. https: //doi.org/10.1016/S1473-3099(09)70104-5

[2] Gubler DJ, Vector-borne diseases. Scientific and Technical Review of the Office International des Epizooties. 2009; 28: 583-88. https://doi.org/10.20506/rst.28.2.1904

[3] Zika situation report July 2016. World Health Organization 2016. Accessed 2016 July 23. Available from: http://www . who. int/emergencies/zika-virus/situa tion-report/14-july-2016/en/

[4] Zika situation report February 2016. World Health Organization 2016. Accessed 2016 July 23. Available from: http://www. who.int/emergencies/zika-virus/situa tion-report/26-february-2016/en/

[5] Zika virus in the United States, 2015-2016. Center for Disease Control and Prevention 2016. Accessed 2016 July 23. Available from: http://www.cdc.gov/zika/geo/united-states.html

[6] Schnirring L. Maps predict areas favorable for zika spread. Center for Infectious Disease Research and Policy 2016. Accessed on 2016 July 25. Available from: http: //www. cidrap.umn.edu/news-perspective/201

6/04/maps-predict-areas-favorable-zika-spread

[7] Norris DE. Mosquito-borne diseases as a consequence of land use change. EcoHealth. 2004; 1: 19-24. https ://doi.org/10.1007/ s10393-004-0008-7

[8] Harris AF, McKemey AR, Nimmo D, et. al. Successful suppression of a field mosquito population by sustained release of engineered male mosquitos. Nat Biotech. 2012; 30: 828-830. PMid:22965050 https://doi.org/10.1038/nbt. 2350

[9] Lacroix R, McKemey AR, Raduan N, et al. Open field release of genetically engineered sterile male Aedes aegypti in Malaysia. PLoS ONE. 2012; 7: 8. PMid:22970102 https://doi.org/10.1371/ journal.pone. 0042771

[10] Nordin O, Donald W, Ming WH, et al. Oral ingestion of transgenic RIDL Aedes aegypti larvae has no negative effect on two predator Toxorhynchites species. PLoS ONE. 2013; 8: 3. PMid:23527029 https://doi.org/10.1371/journal.pone.0058805

[11] Ballenger-Browning KK, Elder JP. Multi-modal Aedes aegypti mosquito reduction interventions and dengue fever prevention. Tropical Medicine and International Health. 2009; 14: 1542-51. PMid:19788717 https ://doi.org/10.1111/j.1365-3156. 20 $09.02396 . \mathrm{x}$ 